\title{
PARAMETERIZATION AND SOLAR RADIATION SIMULATION FOR OPTIMIZATION OF A MODULAR CANOPY
}

\section{PARAMETRIZAÇÃO E SIMULAÇÃO DE RADIAÇÃO SOLAR PARA OTIMIZAÇÃO DE UMA COBERTURA MODULAR}

\author{
Caio de Carvalho Lucarelli ${ }^{1}$ \\ Universidade Federal de Viçosa. Viçosa, MG, Brasil, caio.lucarelli@ufv.br \\ Joyce Correna Carlo ${ }^{2}$ \\ Universidade Federal de Viçosa. Viçosa, MG, Brasil, joycecarlo@ufv.br \\ Andressa Carmo Pena Martinez ${ }^{3}$ \\ Universidade Federal de Viçosa. Viçosa, MG, Brasil, andressamartinez@ufv.br
}

\begin{abstract}
This study perceives the developing process of a parameterization modeling in Grasshopper ${ }^{\circledast}$ for complex surfaces using building simulation, considering diffuse and beam radiation as the key-variables. The primary goal of this article is to create, simulate and optimize a modular, semi-opened canopy based in retro-studies of tree leaves as engineering structures. The method applied consisted of the definition of parameters and criteria for the optimization of the simulation process and was divided into three stages: a study of form, form parameterization, and simulation and optimization. Ladybug ${ }^{\oplus}$ for Grasshopper ${ }^{\circledast}$ plugin was used to carry out the simulations, and Octopus ${ }^{\circledR}$ was used as a motor for optimizing the final script. The object of study chosen was the process of creation of a canopy because, in hot and humid climates, such as in Brazil, the roofing areas are a critical part of the building envelopes that are highly susceptible to solar radiation and other environmental changes, thereby, influencing the indoor comfort conditions for the occupants. Although the final product was created for a specific climate zone, it can be applied to any other zones with a few changes in the parameters due to parameterization. As main results, the solar control devices contributed to a reduction of $86 \%$ of the annual average of hourly beam solar radiation while maintaining high levels of diffuse radiation.
\end{abstract}

Keywords: Ladybug. Pareto front. Optimization based on simulation.

\section{Resumo}

Este estudo compreende o processo de desenvolvimento de modelagem paramétrica em Grasshopper ${ }^{\circledR}$ para superfícies complexas na construção, utilizando, como critérios de desempenho, a radiação difusa e direta. O objetivo principal deste artigo é criar, simular e otimizar uma cobertura modular, semipermeável, baseada no estudo e interpretação de folhas de árvores como estruturas de engenharia. O método aplicado envolveu a definição de parâmetros e critérios para a otimização do processo de simulação e foi dividido em três estágios: estudo da forma, parametrização da forma e simulação e otimização. O plugin Ladybug ${ }^{\oplus}$ para Grasshopper ${ }^{\circledR}$ foi usado para realizar as simulações e o Octopus ${ }^{\circledR}$ foi adotado como motor de otimização. O objeto de estudo escolhido foi o processo de criação de uma cobertura, pois em climas quentes e úmidos, como no Brasil, as áreas de cobertura são uma parte crítica do envelope construtivo, altamente susceptíveis à radiação solar e outras mudanças ambientais, influenciando nas condições de conforto interno dos ocupantes. Devido à parametrização, o produto final, embora criado para uma zona climática específica, pode ser aplicado para quaisquer outras zonas bioclimáticas com poucas alterações nos parâmetros. Como principais resultados, o dispositivo de controle solar contribuiu para a redução de $86 \%$ da média anual de radiação solar horária para radiação direta, mantendo os níveis de radiação difusa.

Palavras-chave: Ladybug. Curva de Pareto. Otimização baseada em simulação.

How to cite this article:

LUCARELLI, Caio de Carvalho; CARLO, Joyce Correna; MARTÍNEZ, Andressa Carmo Pena. Parameterization and solar radiation simulation for optimization of a modular canopy. PARC Research in Architecture and Building Construction, Campinas, SP, v. 10, p. e019017, apr. 2019. ISSN 1980-6809. Available at: https://periodicos.sbu.unicamp.br/ojs/index.php/parc/article/view/8653371. Date accessed: 26 apr. 2019. doi:https://doi.org/10.20396/parc.v10i0.8653371. 


\section{Introduction}

"Considering the importance of buildings in the total energy consumption and the fact that the constructive envelopes are responsible for the thermal exchanges with the [external] environment, as well as the admission of natural light" (CARTANA; PEREIRA; MAYER; 2017, p. 1685), the energy performance of wrapping systems is becoming increasingly important in contemporary architecture, according to Fajkus (2013). In this situation, solar control elements can contribute positively to building performance.

Regarding thermal issues, Cho, Yoo and Kim (2014), evaluating the application of solar control elements, identify that the radiated heat gains in general office buildings in South Korea consumes around 33\% to $40 \%$ of the energy of the construction from May to September with an annual cooling load reduction of maximum $19.7 \%$. Also, Bader and Zitzler (2010) identify the possibility of reduction of beam radiation in $75 \%$, considering the use of the mentioned control elements.

According to González and Fiorito (2015), the integration of natural light and energy performance with the design optimization process has always been a challenge for designers. Most environmental performance simulation tools require a considerable amount of time and interactions to get accurate results. Furthermore, combining goals has always been a problem because different software is required to perform detailed calculations.

As stated by Sadineni, Madala, and Boehm (2011), the buildings we find today are expected to achieve energy efficiency and environmental-friendly design. It is also a common sense that sustainable buildings should encompass various issues regarding energy, water, land and material conservation, as well as environmental pollution and the quality of environments. Despite this common sense, sometimes sustainability does not cover all facets of its object of study.

It is a consensus amongst Sadineni, Madala, and Boehm (2011), Konis, Gamas, and Kensek (2015) and Stevanović (2013), that building energy efficiency can be improved by implementing either active or passive energy efficient strategies. All these references, though, call out for environmental-friendly passive building energy efficiency strategies.

Passive solar design strategies aim to use solar energy to help to establish thermal comfort in buildings, dismissing the use of electrical or mechanical equipment.

Canopies account for large amounts of heat gain/loss, especially in buildings with a large roof area, notably in countries near the Ecuador Line, which is Brazil's case, even though they usually are left aside.

Sunlight is considered the best source of light and it meets best human needs, according to Narangerel, Lee, and Stouffs (2016, p.379). This light penetrates the building by fenestrations that can be both on the facade and the roof. The insertion of radiation inside the building, when accurately calculated, significantly reduces the need for artificial lighting. "In fact, as the literature suggests, natural light provides an environment of better quality and influences the psychological and the way the mind responds, as well as the biological rhythm" (PESENTI; MASERA; FIORITO, 2015, p. 347).

According to Ogbulezie, Ushie, and Nwokolo (2017), diffuse solar radiation plays a vital role in determining light use efficiency, changing the color of the sky and baseline for diffuse solar radiation parameters such as diffuse photosynthetically active radiation, when dealing with photosynthetic organisms. 
"The accurate determination [...] of diffuse solar radiation parameter is required for many applications such as energy management, solar energy, light studies, architectural research [... ]" (NWOKOLO; OGBULEZIE, 2018, p.355).

According to Brotas and Rusovan (2013), architects rely on computational tools to investigate forms and structures. Likewise, these tools cannot only be used for shape generation but also to predict the performance of spaces. "On the one hand, environmental awareness and climate change have affected building regulations. They are increasingly becoming more demanding in terms of energy efficiency and promoting the reduction of $\mathrm{CO}_{2}$ emissions" (BROTAS; RUSOVAN, 2013, s.n.).

Krüger and Laroca (2009), who state in their work that over the last decades, several types of research were concerned with the simulation and evaluation of small systems or individual systems in a building, endorse this statement. "In tropical and subtropical climates, the thermal performance evaluation [...] should be primarily related to the optimization of indoor comfort conditions [...]" (KRÜGER; LAROCA, 2009, p. 661).

In fact, in the last decades, according to Delgarm et al. (2016), considerable research was directed to optimization based on simulation, in order to understand the construction parameters and appropriate architectural configurations to promote its energy efficiency. Besides, Fonseca et al. (2016, p. 267, our translation) state that, "the development of computational technology has led the optimization associated with the parameterization to enable the development of projects with better performance, with or without integration with the simulation."

Over the past twenty years, the work of creating solar protection, regardless of the face of the building, was manual, and variations such as latitude, longitude, building rotation, geometry modification, and others, required analog rework. According to Eltaweel and Su (2017), in the contemporary conception of architecture, all these aspects in their dimensions can be considered parameters and with the application of the correct software, it is possible to assemble a complete base, which can be altered and improved with efficiency, so that the design of the building simultaneously changes without rework. Jakubiec and Reinhart (2011) share these same thoughts.

The term parametric originates from mathematics and refers to using specific parameters or variables, which can be amended in order to manipulate with the equation results. Eltaweel and Su (2017, p. 1087) state that, "[...] the principle of parametric design can be defined as a mathematical design, where the relationship between the [...] elements are shown as parameters which could be reformulated to generate complex geometries [...]". These geometries are based on the elements' parameters. By changing these parameters, new shapes are created simultaneously.

Andrade and Ruschel (2009) have identified that publications on the use of parametric modeling programs have emerged no more than a decade in Brazilian Conferences. Santana, Guimarães and Carlo (2015) infer that, although parameterization has been applied to energy efficiency studies for almost two decades in Brazil, the evaluations that take into account shape parameters are recent due to the computational advances implemented in the current decade.

Nowadays, parametric design is used in many fields, disciplines that consist of complex algorithmic relations, interdisciplinary work, creative forms, and multiprocessing treatments such as AEC (Architecture, Engineering, and Construction). It is not easy to control these operations using conventional tools or imagine them using our analogical thinking, so it is needed to use complex operating systems, parametric tools, and specific software. Due to this digital and technological development, we can find many 
implementations of parametric design in many fields like decoration, fashion, architecture, urban planning, sonic study, structural analysis, medicine and so on (ELTAWEEL; SU, 2017, p. 1090).

Eltaweel and Su (2017) state that daylight and radiation are influenced by many divergent criteria such as longitude, latitude, sun path, sky type, solar radiation, humidity, territory, among others. All of these aspects have different parameters and are influenced by each other. Therefore, parametric design can provide this utility by connecting these data using specific software, which can ease the design decision, modeling, and solving problems. Furthermore, it could anticipate the optimum solutions for the building design especially via analyzing the influence of daylight.

"Studies have demonstrated the potential use of tools to analyze the performance of the constructive envelope for energy optimization or visual aspects" (FELIPPE et al., 2015, p. 398) and because of the repetitive nature of the procedures, to achieve them, this optimization is automated. In short, modeling software Rhinoceros $3{ }^{\circledR}{ }^{\circledR}$, its DIVA ${ }^{\circledR}$ plugin, Ladybug ${ }^{\circledR}$, HoneyBee ${ }^{\circledR}$, Grasshopper ${ }^{\circledR}$, and EnergyPlusTM building-modeling programs are often cited.

According to Gossard, Lartigue, and Thellier (2013, p. 253), "improving the thermal performance of a building can be done in two ways. The first approach is based on a trial-and-error method [...] and the second approach ensures a more reliable method by using optimization algorithms". Although the "'trial-and-error' processes may be able to generate acceptable solutions, they are doubtful to achieve near-optimal designs" (MAGNIER; HAGHIGHAT, 2009, p. 739). For this reason, the optimization using genetic algorithms is seen as an option with higher chances of indicating the best solutions for a project according to its objectives and constraints.

With the advances in computational design, parametric optimization and building performance simulation, researchers such as Eltaweel and Su (2017) and Pesenti, Masera and Fiorito (2015), believe that what is necessary for the continuous development of generative methods with integrated approaches is only to explore the project from biases that have not yet been explored.

As claimed by De Focatiis and Guest (2002), the analysis of tree leaves as engineering structures is a relatively recent one. Most leaves can be modeled as thin membranes or laminae with reinforcements in the form of veins and midribs. "The leaf is a compromise in flexibility and rigidity. It is the interaction of these stiffening members and the flexible membrane panels that leads to an interesting mechanism" (DE FOCATIIS; GUEST, 2002, p. 227).

The advantage of the leaf-folding patterns can be seen when several membranes of the leaf are joined to produce polygons. "The leaves can be arranged in two basic ways, either pointing towards the center of the polygon, leaf-in, or directed away from it, leafout" (DE FOCATIIS; GUEST, 2002, p. 228). The folds of different leaves can be interconnected and are compatible with each other. This way, the whole structure can be folded and unfolded from a single or multiple driving points.

In conclusion, the goal of this paper is to evaluate the process of creation of a modular canopy based on biomorphic shapes, capable of allowing the entry of radiation indoors, maximizing diffuse incident radiation per $\mathrm{m}^{2}$ and minimizing beam radiation according to solar geometry, through computer simulation. 


\section{Method}

This research is of quantitative and exploratory type (GROAT, 2013) inserted in the area of Performance-Based Design, involving simulations for radiation and optimization. Methods aiming at the analysis of a design process based on optimization are emphasized. For instance, the method adopted by Pesenti, Masera, and Fiorito (2015) and González and Fiorito (2015) were the main ones used in this study, because of the approximation to the study of forms applied to complex surfaces. Thus, the research was divided into three stages. The first stage concerns the exploration and definition of the form; the second stage regards the parameterization of the canopy and the third stage concerns simulation for radiation and optimization of the design.

\section{First Stage}

The work was carried out following an interpretation of the methodology applied by authors such as Pesenti, Masera and Fiorito (2015), Cheng et al. (2015), ElGhazi and Mahmoud (2016) and González and Fiorito (2015) and was divided into three parts. The first part follows the bias of the investigation of the form. This is a critical phase for the project since the design must start from a simplified approach so that its reproduction can occur without difficulty, given the formal complexity usually applied in parametric geometries.

Academic research evidenced by Pesenti, Masera and Fiorito (2015), Mahmoud and ElGhazi (2016) and De Focatiis and Guest (2002), contemplate geometric forms based on origami and branches and leaves, since the kinematics created by the fold of the geometries surpasses the variety of angles allowed by a Euclidean geometry, besides being considered adaptive forms. It is a system that easily deforms, creating patterns capable of reducing the use of material, increasing structural rigidity and retaining lightness, one of the principles discussed by Buckminster Fuller's theory of "Tensegrity"(1).

In some leaves and flowers, a folding technique is used efficiently to optimize their shapes continuously. De Focatiis and Guest (2002, p. 227) point that "Hornbeam and Beech leaves have a particularly simple and regular corrugation pattern [...] that is strengthened by the distortion induced in the cantilevered corrugation". Thanks to that, they have been taken as inspiration for engineering structures. Hornbeam, Beech and Maple leaves exhibit a deployment mechanism; the pleats are disposed like V-shaped patterns in a way to allow young leaves to fit into the buds.

In the opinion of Pesenti et al. (2015, p. 663), leaves motion, like Oxalis Triangularis, has to be considered as nastic movements, "where active structures respond to an external stimulus independently of direction, inducing a reversible movement - the folding/unfolding of the leaf." Therefore, learning from nature may be particularly useful for a biomimetic translation into the design of a kinetic shading device.

For this research, forms of nature were used, more specifically, abstractions of leaves (Figure 1) as a starting point, taking into account their organicity and ability to behave hastily, while creating protection from weather, one of the premises of the project.

It consists in the use of Rhinoceros $3 \mathrm{D}^{\circledast}$ and Grasshopper $^{\circledast}$ to assemble a script that allows variation of the design according to its geographical positioning. 
Figure 1 - Creation of shape based on the leave natural form. Division indicates the upper and lower dampers

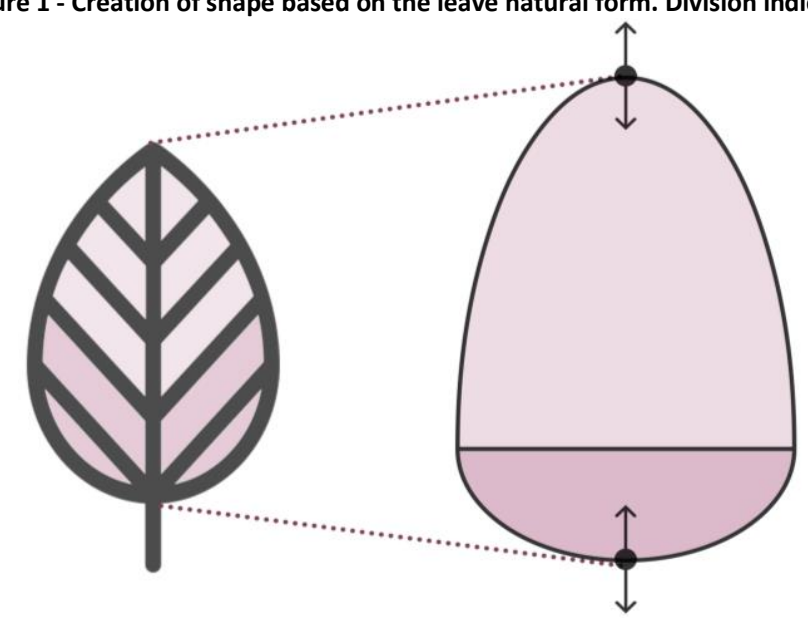

Font: The authors.

\section{Second stage}

The variability of the project is based on the possibility of implantation of it in different latitudes and longitudes, depending on the weather file used. In this experiment, the weather file TMY 3 for the city of Viçosa (Latitude $20^{\circ} 45^{\prime} 14^{\prime \prime} \mathrm{S}$, Longitude $42^{\circ} 52^{\prime} 55^{\prime \prime} \mathrm{W}$, Altitude $648 \mathrm{~m}$ ), MG, was used (GUIMARÃES, 2016). The purpose of creating this script is that, with the modification of small parameters (Figure 2), such as module size, height, angulation, opening area, among others, it is possible to generate an optimized form. This modification is allied to the solar masking for the specific latitude in which the project is located.

Figure 2 - Script relationships in the Grasshopper ${ }^{\circ}$ plugin adding the multiplier to the number slider and to the scale in $Y$-axis, preventing upper damper to be larger

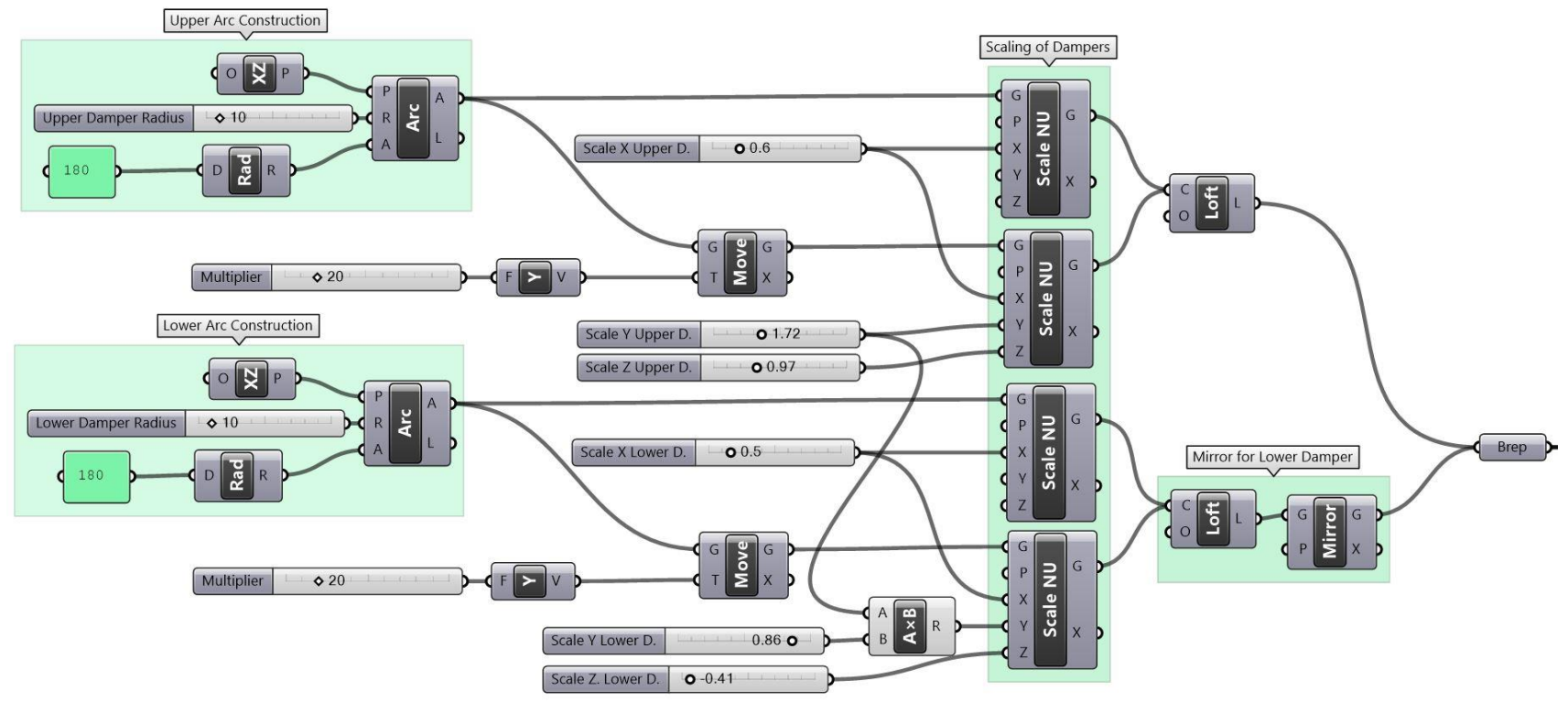

Font: The authors.

The initial module was divided into two parts, and two modifiable parameters were applied for each of these parts (Figure 3). Thus, the module can vary in aperture and length at its top or bottom. For its lower part not to be larger than the upper one, and then to prevent entering radiation and to avoid water accumulation on the inside damper, a multiplier has been added (Figure 2). Its $Y$ scale factor will depend on two values, which are the scale and the multiplier, a diminishing factor. 
Figure 3 - Module and axis of movement. In the module, variations in size are represented in $X$ and Z-axis, while $Y$-axis is maintained unchanged
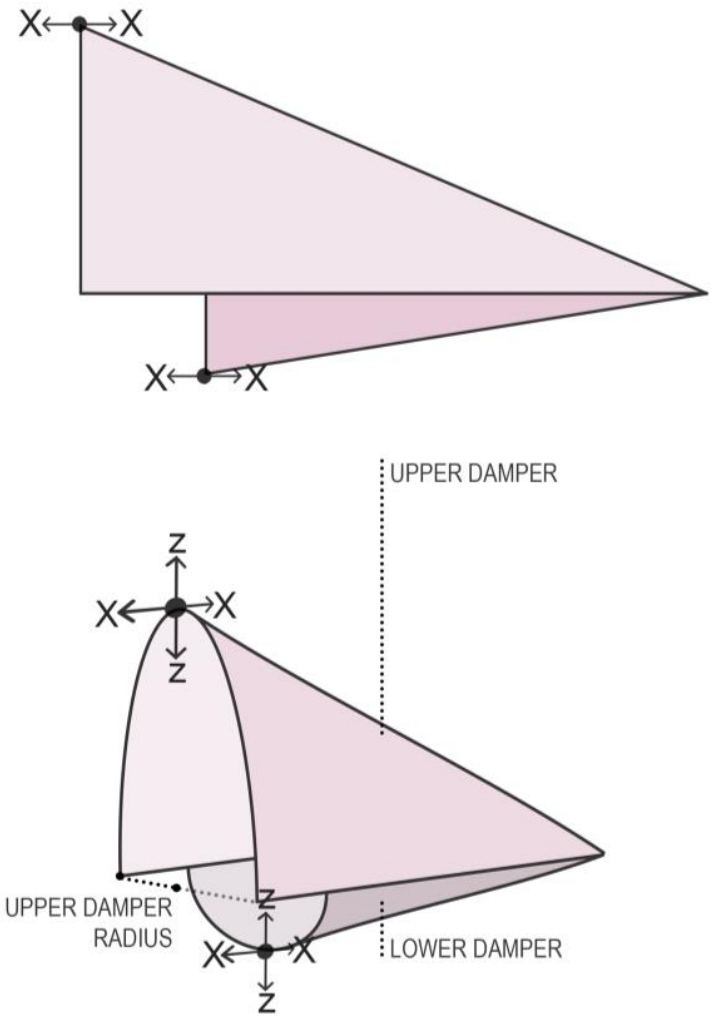

Font: The authors.

All openings are facing north to allow beam radiation incidence in the case studies, leading to cases in which this radiation will be minimized.

Considering the need to measure the levels of beam and diffuse radiation, a plan of analysis was created just below the structure of the Canopy (Figure 4), much smaller than the extension of the modules, so that the radiation coming from the sides of the structure would not reach it and affect the final calculations. For the evaluation of the radiation, the plugin Ladybug ${ }^{\circledR}$ for Grasshopper ${ }^{\circledR}$ was used.

According to Cheng et al. (2015, p. 323), analyzing solar radiation of simple motifs is the first step in a simulation, helping with the understanding of the following situations. The efficacy of these simulations can be interpreted and help initiate design decisions for building skins. The quantitative results from radiation simulations can improve understanding of the consequences of complex patterning, driving design refinement. (KHORASGANI; BURRY; SALEHI, 2014).

LadyBug $^{\oplus}$ was chosen for the radiation analysis because, according to Roudsari and Pak (2013), Ladybug ${ }^{\circledR}$ imports standard EnergyPlus Weather files (.epw) into Grasshopper ${ }^{\circledR}$ plug-in and provides a variety of $2 \mathrm{D}$ and $3 \mathrm{D}$ interactive graphics to support the decisionmaking process during all stages of design. It also simplifies the analysis process, automates and expedites the calculations, and provides easy to understand and to manipulate graphical visualizations in the 3D modeling interface of Rhino/Grasshopper ${ }^{\circledR}$. "It also allows users to work with validated energy and daylighting engines such as EnergyPlus, Radiance, and Daysim" (ROUDSARI; PAK, 2013, p. 3128). 
Figure 4 - Top view of modules and analyses plan for radiation and the treatment received by the modules
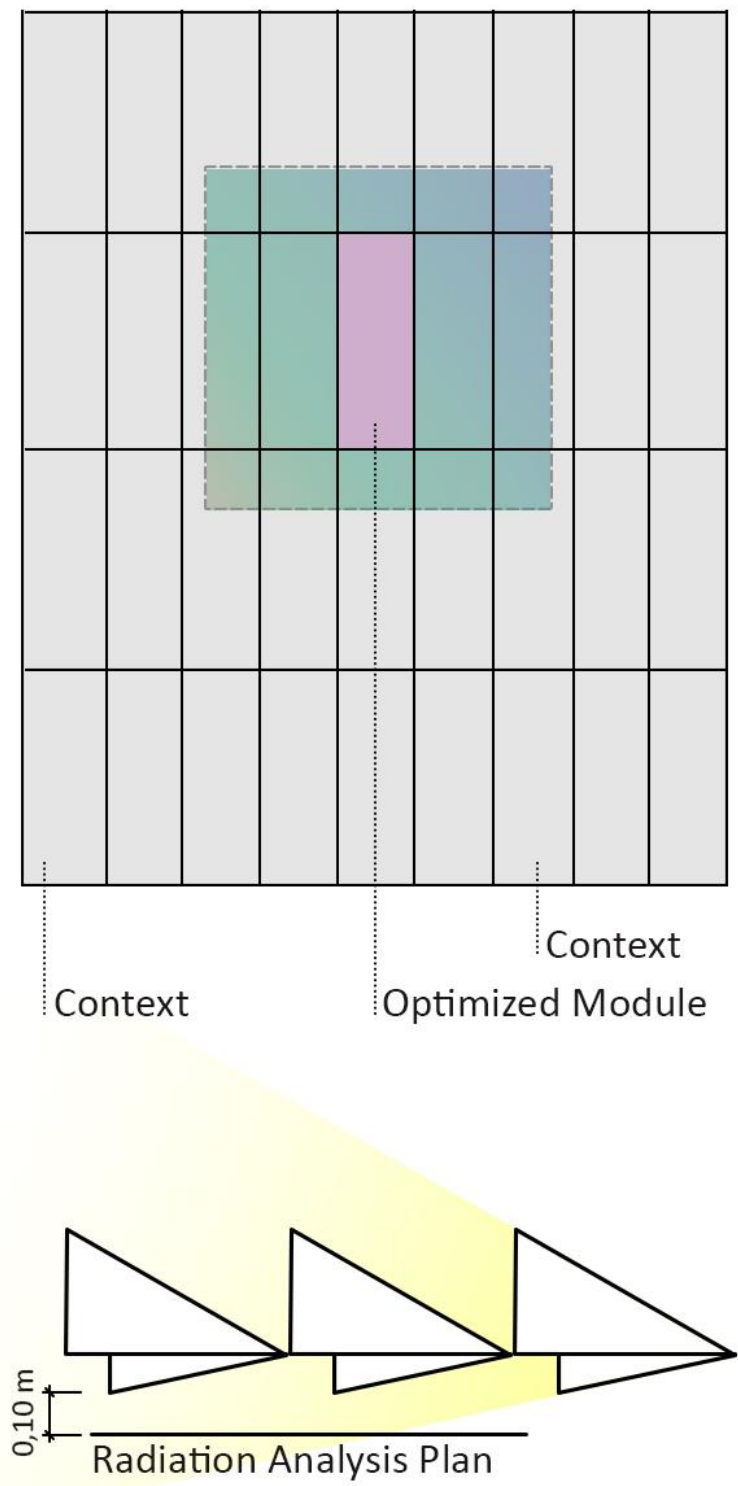

Font: The authors.

\section{Third stage}

It regards the simulation and optimization using Ladybug ${ }^{\circledR}$ and Octopus ${ }^{\circledR}$ plugins for evaluation of the incident radiation per square meter. According to Fonseca et al. (2017, p.267), Octopus ${ }^{\circledR}$ "enables the user to work with two or more goals, such as the 'diversify parameters' option", which increases the chances of algorithm exploration in the entire search field of solutions. Octopus ${ }^{\circledR}$ plugin for Rhino ${ }^{\circledR}$ also allows the use of two genetic algorithms in the optimization: HypE or SPEA-2. The plugin "also makes it possible to determine the size of the population that will be created within each generation" (FONSECA et al., 2017, p. 267), allowing the user to establish a maximum number of generations. In this study, SPEA-2 was used.

According to Zitzler, Laumanns, and Thiele (2001), SPEA-2 is an elitist evolutionary algorithm created by the authors mentioned above that present evolution when compared to his predecessor. It was tested and compared to its predecessor and other 
two popular genetic algorithms based on elitist methods (PESA and NSGA-II) and presented promising results.

Considering the use of Ladybug ${ }^{\circledR}$ and its capacity to evaluate radiation we chose to work with diffuse radiation maximization and beam radiation minimization (Figure 5), composing a multi-objective optimization.

According to Nguyen, Reiter, and Rigo (2014), optimization can be classified according to the number of objective functions. It can be a mono or multi-objective optimization, although Nguyen, Reiter, and Rigo (2014) identified that $60 \%$ of building optimization studies had only one objective function. Multi-objective optimization, on the other hand, approaches more of real problems, since designers usually need to deal with conflicting design criteria (NGUYEN; REITER; RIGO, 2014).

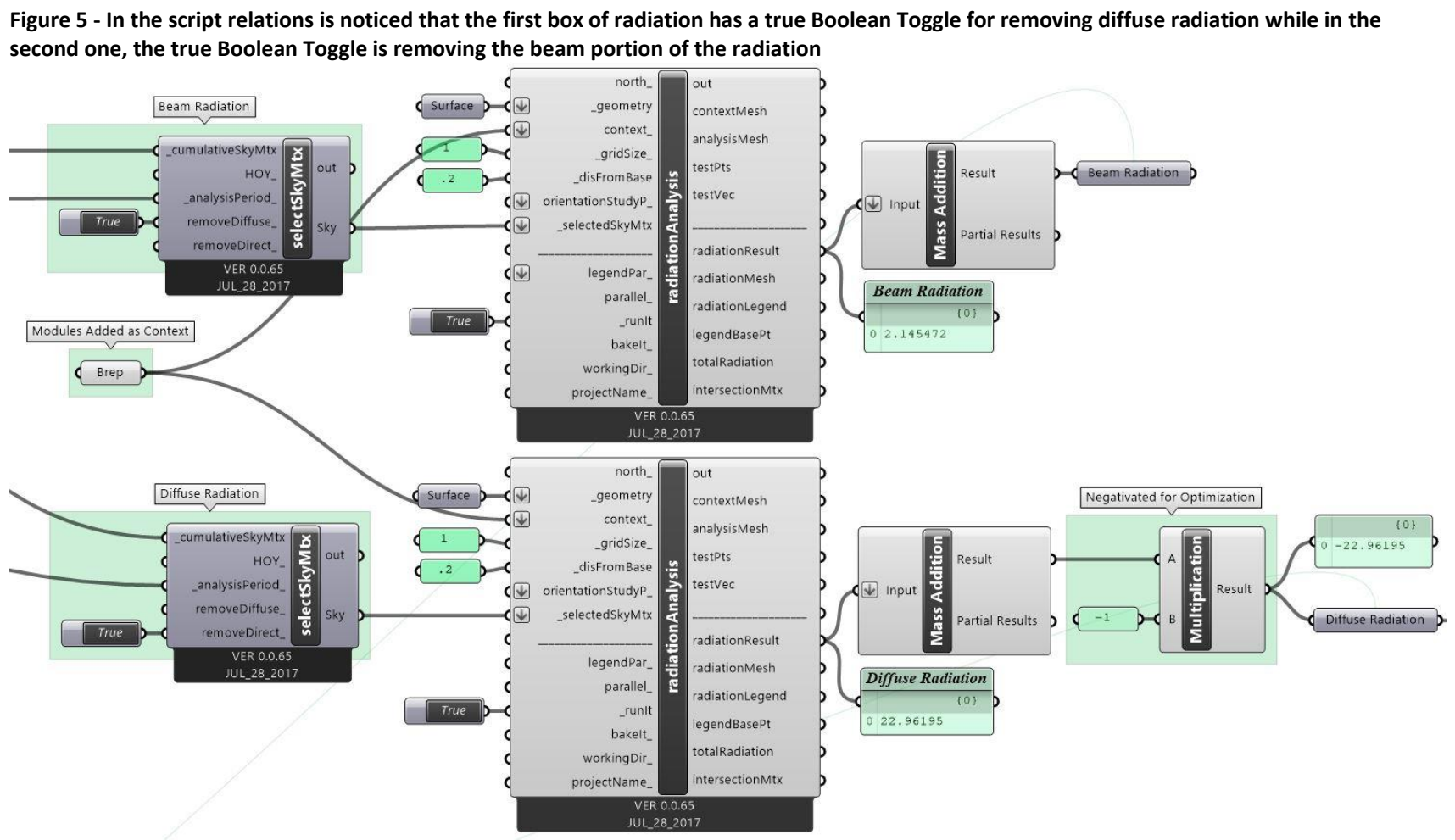

Font: The authors.

According to Evins (2013), evolutionary algorithms are amongst the most common in optimization. They are based on Darwin's theory of evolution, in which populations of solutions are created, and each of these is evaluated according to their performance. They use a principle of "natural selection to evolve a set of solutions towards an optimum solution" (MACHAIRAS; TSANGRASSOULIS; AXARLI, 2014, p. 103). With each generation created, the poor performers are eliminated from the population (EVINS, 2013), while the best are kept for the next generation creation and selection process.

According to González and Fiorito (2015, p. 561), they use techniques such as "inheritance, mutation, selection, and crossover to evolve a solution for general or specific problems." They have been proven to be an effective strategy for addressing multi-objective design problems and calculate multiple performance criteria, finding close to optimum solutions in a short period. However, their application requires extensive mathematical and computer programming knowledge, far beyond the domain of most professionals. The creation of Octopus ${ }^{\circledR}$ has filled this gap. 
This part of the methodology combining Octopus ${ }^{\circledR}$ with performative plugins could be one of the answers to ensuring high levels of environmental performance while reducing the time needed for extensive trial and error processes. "Simulations can be performed automatically and the results stored and organized according to their performance" (GONZÁLEZ; FIORITO, 2015, p. 561).

For data analysis, Vilfredo Pareto proposes one of the most popular methods to present multi-objective solutions. "A solution is Pareto optimal or nondominated when there isn't any other feasible solution that improves one objective without deteriorating at least another one" (MACHAIRAS; TSANGRASSOULIS; AXARLI, 2014, p. 102). When the problem consists of two objectives, the Pareto frontier can be represented as a curve.

Also known as Pareto Analysis, the $A B C$ Curve is a method used to organize points in order of relevance, in which $20 \%$ of the factors usually cause $80 \%$ of problems. For the analysis of the data collected in the simulation and optimization, one of the methods consisted of the creation of an ABC Curve.

"The $A B C$ curve is a method of classifying information, so that items of greater importance or impact are separated, which are usually in smaller numbers" (CARVALHO, 2002, p. 226). It is a statistical classification of materials based on the Pareto principle, which considers the importance of materials based on the quantities used and on their value.

To divide total radiation into two plots it was necessary to break the script into two parts, one containing a true toggle only for the beam plot of radiation, and the other containing a positive toggle only for the diffuse plot of radiation (Figure 5). In the Octopus ${ }^{\otimes}$ plugin, a third objective was added by asking for Diversification of Parameters in order to ensure that the optimization engine searches the entire solution space and does not run the risk of being stuck in a local search, which could lead to a loss of potential solutions.

The parameters used were movement in the $Y$ and $Z$-axis in the upper and lower damper, as it was discussed earlier in the paper, totalizing four parameters besides the diversify parameters.

Octopus ${ }^{\circledR}$ is started with a population size of 100 and Max generations of 50 to make optimization feasible. The plugin allows the user to choose a solution for analyzing parameters and performance indicators visually. According to Fonseca et al. (2017, p. 267) "its relevance as an optimization engine for Grasshopper ${ }^{\circledR}$ is also to avoid that the optimization is interrupted when faced with cases impossible to reach a viable solution." It automatically skips the case if the user determines a maximum evaluation time for each simulation.

During the simulation, the convergence of solutions will be used as a stop criterion. The point of convergence is defined by looking at the graph provided by Octopus ${ }^{\circledR}$.

\section{Results and discussion}

The convergence of the model occurred in generation 33 (Figure 6). The first Parameter Graph (a) is from the first generation and the second (b) is from the thirty-third generation when the convergence is seen. The units concern to the annual average of hourly solar radiation considering 12 hours of daylight, using the TMY 3 Weather File for Viçosa (Latitude $20^{\circ} 45^{\prime} 14^{\prime \prime} \mathrm{S}$, Longitude $42^{\circ} 52^{\prime} 55^{\prime \prime} \mathrm{W}$, Altitude $648 \mathrm{~m}$ ) (GUIMARÃES, 2016). In the parameter graph, each solution is presented as a line connecting the parameters; the closer the lines, the more the project approaches convergence. 
Based on the data provided, a dispersion graph was created for further analysis (Figure 7). According to Delgarm et al. (2016, p. 295), "[... ] in the multi-objective optimization problems, all points on the Pareto front are potentially an optimum solution".

In this respect, the selection of the final optimum configuration among the available optimal points requires a process of decision-making.

Figure 6 - Parameters convergence of generation 01 (left) and generation 33 (right)

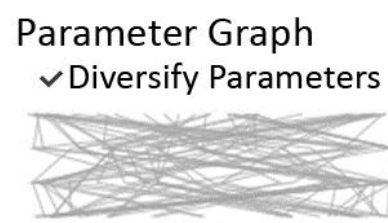

(a)

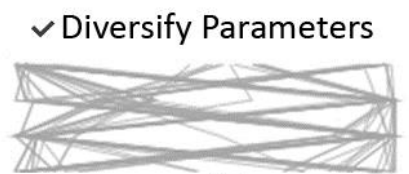

(b)

Font: The authors.

The graph (Figure 7) is divided into three classes: A, B, and C. In class A, the elements found have greater importance, value or quantity, corresponding to $20 \%$ of the total, class B has intermediate importance, quantity or value and corresponds to $30 \%$ of the total, while class $\mathrm{C}$ corresponds to $50 \%$ of the total and has minimum status. Taking into consideration the Pareto Frontier, the results that form the curve are considered a nondominated solution, even though any other point in the Figure 7 could be considered feasible solutions, according to Machairas, Tsangrassoulis and Axarli (2016).

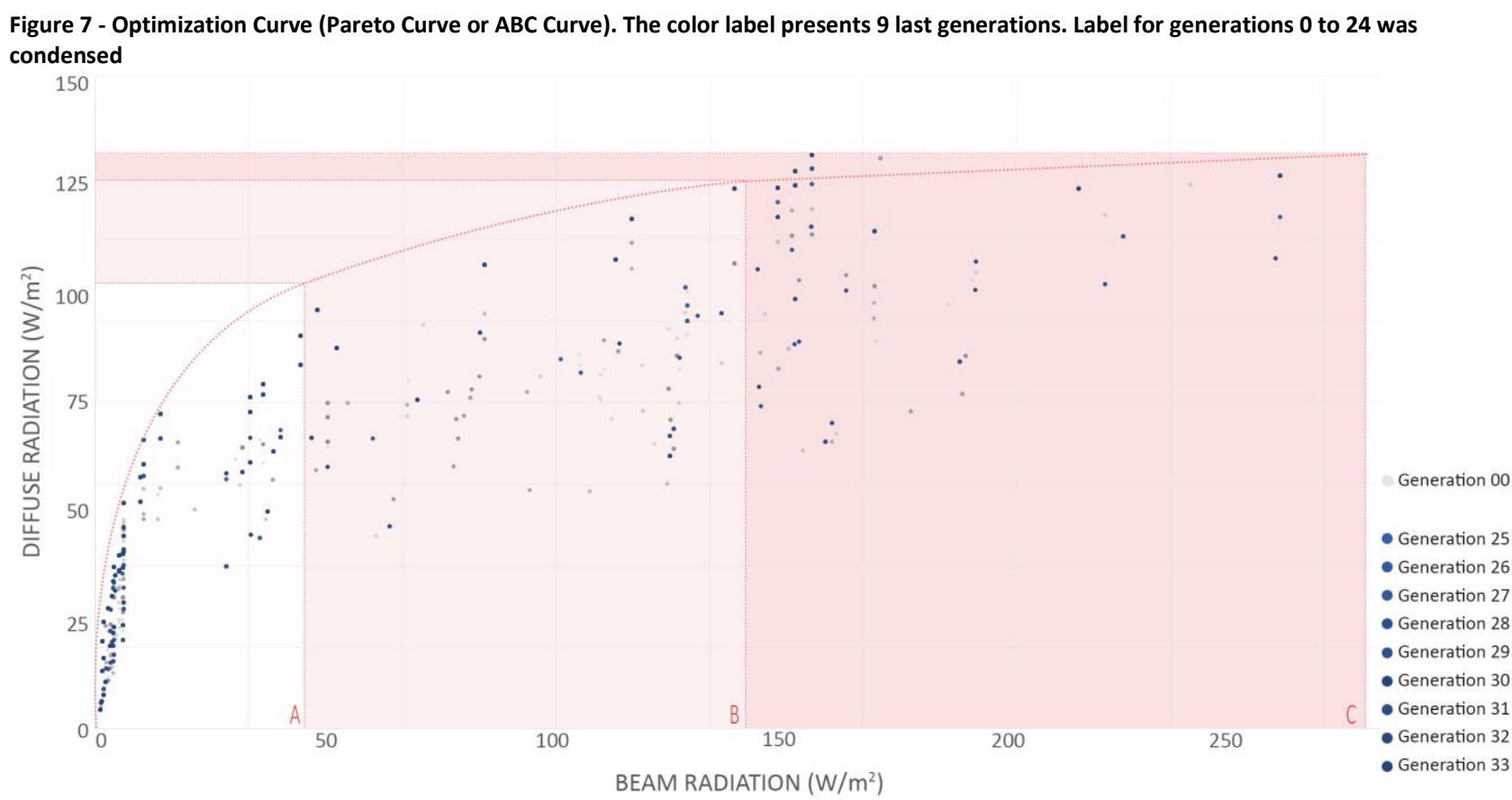

Font: The authors.

As seen in the Pareto front, most results close to the convergence are in group $A$, and a small amount of them is in group B (Figure 8).

Taking into account that the optimization concentrates the best results in the last generations and that the best results are found in Group A according to the ABC curve, three solutions were selected as the best ones because of their higher diffuse radiation values (Figure 9). 
Figure 8 - Four last generation's placements in the ABC Curves

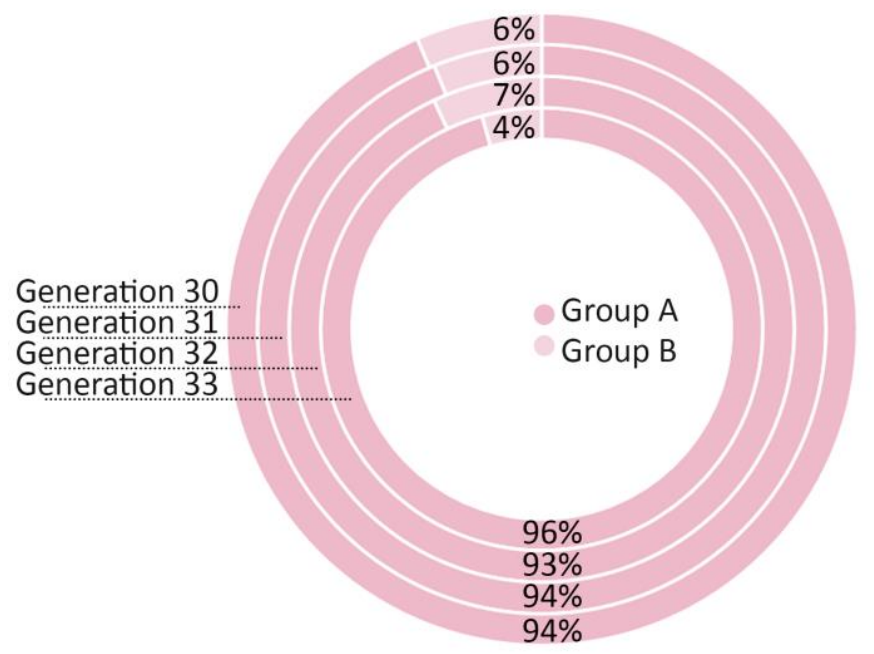

Font: The authors.

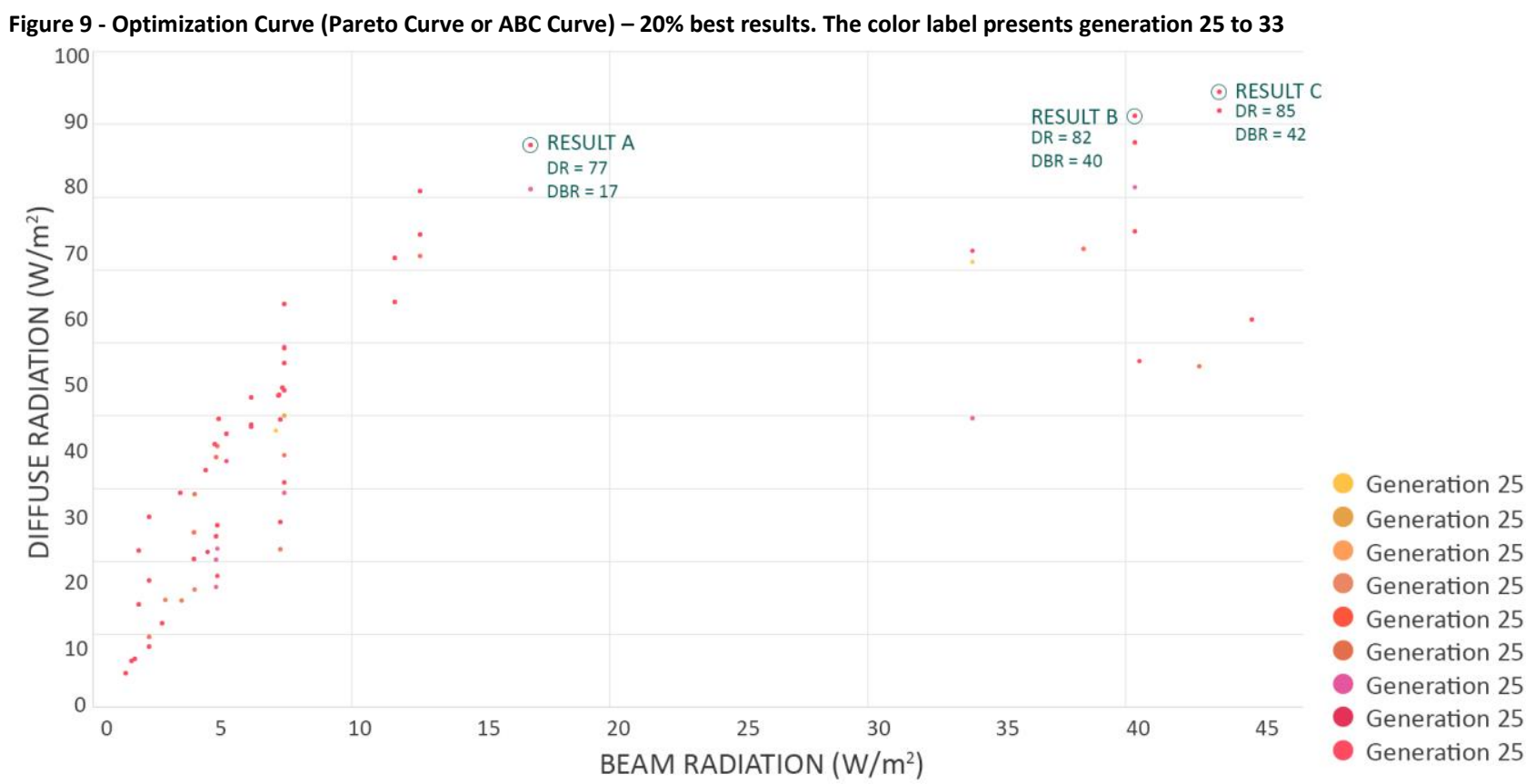

Font: The authors.

Among the diffuse solutions that were not chosen, the annual average reached up to $175 \mathrm{~W} / \mathrm{m} 2$ for hourly diffuse and $85 \mathrm{~W} / \mathrm{m} 2$ for hourly beam radiation. It can be seen that the optimization kept diffuse radiation high, reaching and surpassing the average annual values.

This can also be seen while comparing the simulation results to the hourly solar radiation obtained from the TMY 3 file. The weather file diffuse radiation (Figure 10) presents higher values in the rainy summer and especially in spring hours, December to March and September to December respectively. It also presents a valley in the winter season, June to September. The optimized results of the annual average of hourly radiation below the canopy for the solutions of the last generation reached values comparable to spring and summer, about $175 \mathrm{~W} / \mathrm{m} 2$, which means a reduction of $20 \%$ compared to the highest level of diffuse radiation. For the optimized results, there is a reduction of $14.5 \%$ 
for result $A, 8.8 \%$ for result $B$ and $5.5 \%$ for result $C$, when compared to the annual average.

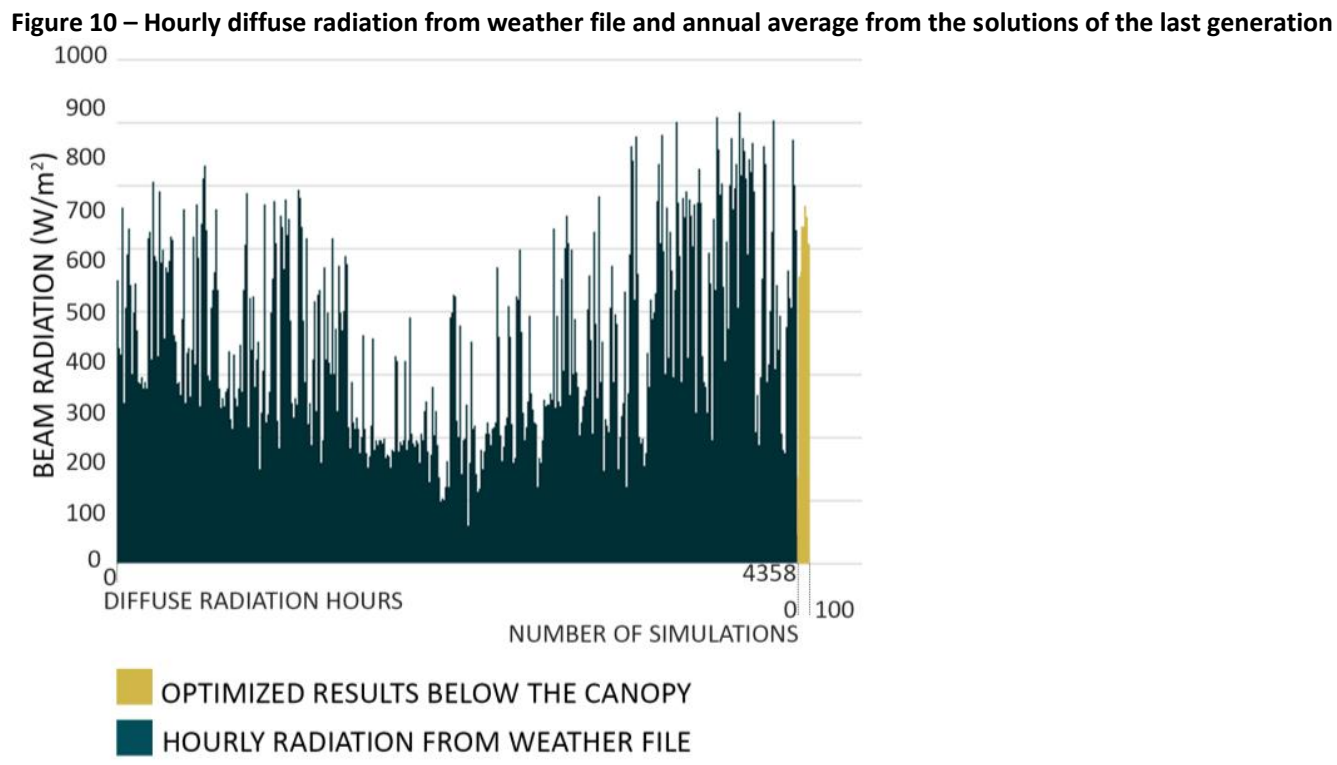

Font: The authors.

For beam radiation (Figure 11), there is also a peek in summer and spring hours with a low bound during the winter time. Since the scope of the optimization was to minimize beam radiation and maximize the diffuse portion, the levels of radiation achieved were as low as $17 \mathrm{~W} / \mathrm{m} 2$ for result $A$, the equivalent of a reduction of $94.5 \%$ when compared to the weather file annual average. For result $B$, beam radiation was $40 \mathrm{~W} / \mathrm{m} 2$, a reduction of $87.5 \%$ and for result $C$, beam radiation was $42 \mathrm{~W} / \mathrm{m} 2$, and the reduction was of $86.8 \%$.

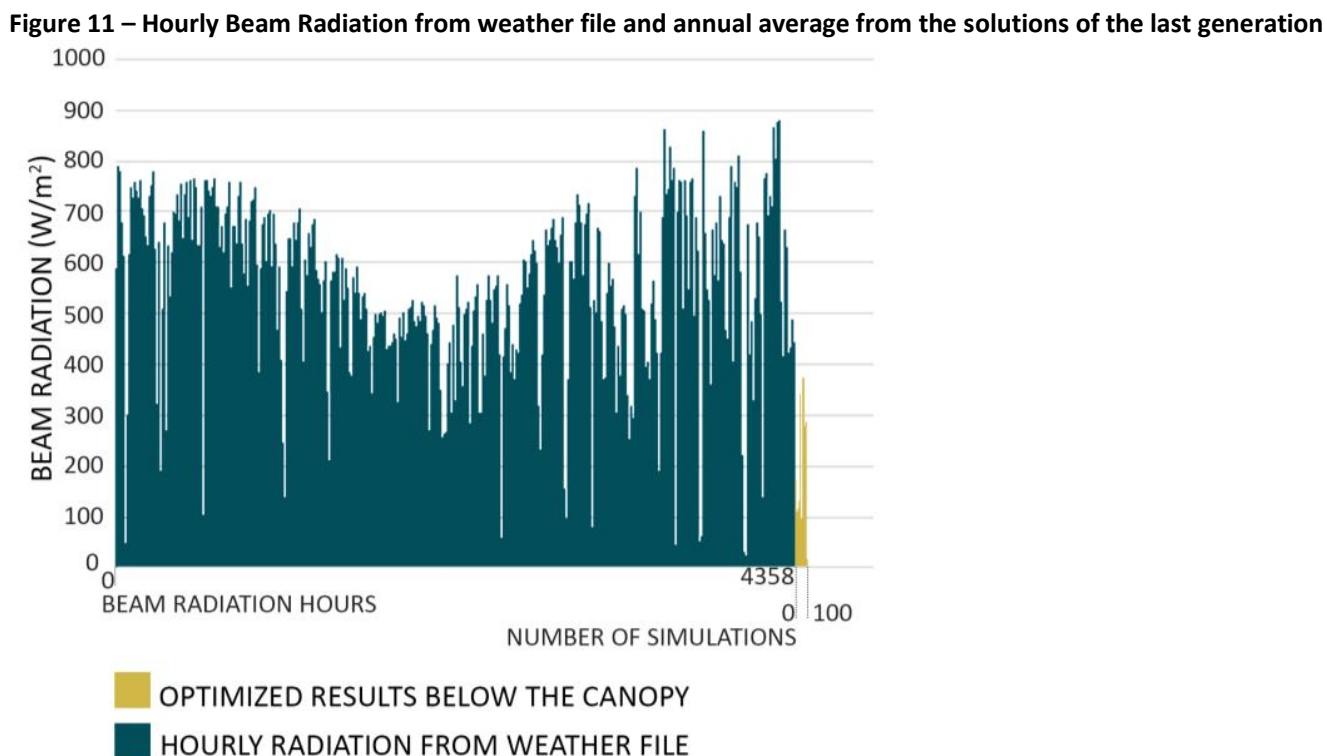

Font: The authors.

When it concerns the parameters, the input data in Grasshopper ${ }^{\circledR}$ for the results shows a low variation of values for some parameters and a high variation for others (Figure 12). Therefore, one to believe that the optimization depended on the combination of parameters 1, 2 and 3, responsible for scale in $Y$ and Z-axis for the upper damper and scale in $\mathrm{Y}$-axis for the lower damper, with the multiplication factor, respectively. 
Parameter 4, responsible for scale in Z-axis for the lower damper, had little effect in the optimization.

Figure 12 - Comparison of variability of parameters input data for three chosen results

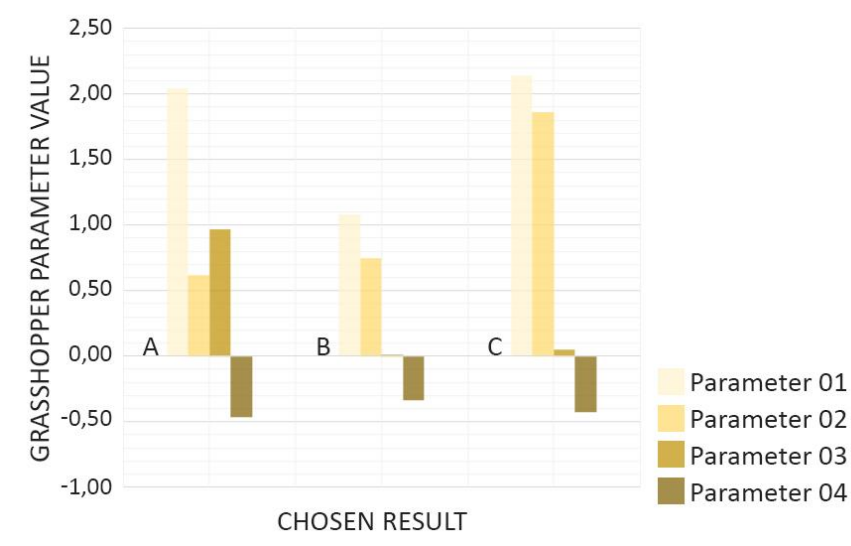

Font: The authors.

The analysis of the best results in the four last generations is consistent with the evaluation of all the results, which implies that the Z-axis values for the lower damper were not definitive for the result and it confirms what was designed (Figure 13). The three selected results are shown in order and, in all three results, we can see that the bottom damper of the model was not maintained in the bottom portion of the module, due to the optimization process.

Figure 13 - Three canopy geometries generated and chosen in the optimization process
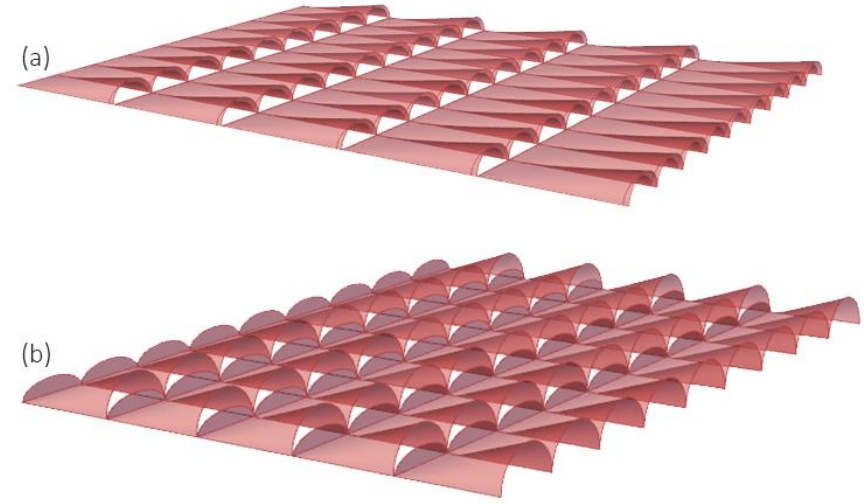

(c)

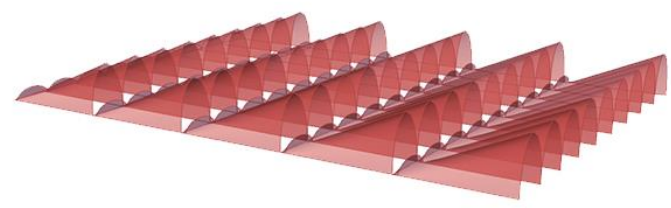

Font: The authors.

An explanation for this fact is the occurrence of the reflection on the outside of the module, mainly in the upper damper, and not in its interior, as imagined at the beginning of the study. In order to avoid the direct portion of radiation, the model inverted the bottom lappet, creating an upper flap. Thus, the lower damper was automatically incorporated to the upper part of the module, helping diminish the portion of bean radiation penetrating the canopy. 


\section{Conclusions}

To design is to anticipate the creation of forms in the material world. In order for the project to be thought and transmitted to all participants in the process, it has to be represented in 2D and 3D. Consequently, the architect should materialize its ideas into representations.

Computational optimization can differ from traditional methods, providing new answers for design problems that can be more effective in solving specific tested issues.

For the studied case, the optimized solution performs significantly better regarding radiation availability, having the beam portion of radiation below the canopy diminished up to $94.5 \%$ for the best-case scenario when compared to the annual average, maintaining diffuse radiation close to the average values of the weather file for all of the chosen solutions. For cases $\mathrm{B}$ and $\mathrm{C}$ the hourly beam radiation under the canopy was diminished by $87.5 \%$ and $86.8 \%$ respectively.

The results presented as Pareto solutions in the $A B C$ curve indicated the importance of the designer's decision, primarily in the choice of the final solution, since the curve and the selection of data have to be made by the researcher.

The tools used in the simulations and optimization, although not yet ingrained among designers and presenting limitations, proved their potential for integration between the design process and specific areas in architecture and engineering, such as performance analysis.

Besides, because the software and the plugins used are recent technology amongst architects and engineers, there is a promise of rapid advance in the next 10 to 20 years. Several of the computational tools used are in the improvement phase and have been updated during the development of the model.

This project is an exploratory project of the potential application of the tools used to optimize the dimensions of the modules of a canopy, to satisfice radiation solutions following a straightforward application of parameters.

Future studies can be built upon the current one and explore an expanded set of optimization criteria, combining energy-related indicator with visual comfort ones, such as glare probability and uniformity of daylight illuminance. In conclusion, the results demonstrate that the integration of computational design and performance simulations for solar control elements with complex shapes is essential for selective admission of solar radiation.

\section{Acknowledgements}

We thank Fundação de Amparo à Pesquisa do Estado de Minas Gerais (FAPEMIG) for the scholarship (5273/15).

\section{Notes}

(1) According to Calladine (1978), in the first decades of the twentieth century, kinetic architecture was completely theoretical. In 1940 innovators, such as Buckminster Fuller, began experiments in this area, even if unsuccessfully. Despite this, much of what was produced by Fuller was used. His theory known as "Tensegrity" was incorporated into robotics, popularized in the 1980s. This theory was based on the combination of simple designs in pure traction or compression. 


\section{References}

ANDRADE, M. L. V. X.; RUSCHEL, R. C. BIM: Conceitos, Cenário das Pesquisas Publicadas no Brasil e Tendências. In: SIMPÓSIO BRASILEIRO DE QUALIDADE DO PROJETO NO AMBIENTE CONSTRUÍDO, 1., 2009, São Carlos. Anais [...]. Porto Alegre: ANTAC-EESC/USP, 2009.

BADER, J.; ZITZLER, E. HypE: an algorithm for fast hypervolume-based many-objective optimization. Evolutionary computation, v. 19, n. 1, p. 45-76, mar. 2011. DOI:https://doi.org/10.1162/EVCO_a_00009

BROTAS, L.; RUSOVAN, D. Parametric Daylight Envelope. In: CONFERENCE SUSTAINABLE ARCHITECTURE FOR A RENEWABLE FUTURE, 29., 2013, Munique. Proceedings [...].Munique: 2013, p. 304-322.

CARTANA, R. P.; PEREIRA, F. O. R.; MAYER, A. Estudo Piloto para Análise de Elementos de Controle Solar com Formas Complexas. In: ENCONTRO NACIONAL DE CONFORTO NO AMBIENTE, 16., 2017, Balneário Camboriu. Anais [...]. Balneário Camburiú: ENCAC, 2017, p. 1684-1694.

CHENG, N. Y.; KHORASGANI, M. L.; WILLIAMS, N.; PROHASKY, D.; BURRY, J. Understanding Light in Building Skin Design. In: THE ASSOCIATION FOR COMPUTER-AIDED ARCHITECTURAL DESIGN RESEARCH IN ASIA, 20., 2015, Hong Kong. Proceedings [... ]. Hong Kong: 2015, p. 323-332.

CHO, J.; YOO, C.; KIM, Y. Viability of exterior shading devices for high-rise residential buildings : Case study for cooling energy saving and economic feasibility analysis. Energy \& Buildings, 2014. p. 771-785.

DOI:https://doi.org/10.1016/j.enbuild.2014.07.092

DELGARM, N.; SAJADI, B.; KOWSARY, F.; DELGARM, S. Multi-objective optimization of the building energy performance: A simulation-based approach by means of particle swarm optimization (PSO). Applied Energy, Tehran, v. 170, p. 293-303, may 2016. DOl:https://doi.org/10.1016/j.apenergy.2016.02.141

ELGHAZI, Y. S.; MAHMOUD, A. H. A. Origami Explorations: A Generative Parametric Technique for Kinetic Cellular Façade to Optimize Daylight Performance. In: EDUCATION AND RESEARCH IN COMPUTER AIDED ARCHITECTURAL DESIGN IN EUROPE, 34., 2016, Finlândia. Proceedings [... ]. Finlândia: eCAADe, 2016, p. 399-408.

ELTAWEEL, A.; SU, Y. Parametric design and daylighting: A literature review. Renewable and Sustainable Energy Reviews, Nottingham, v. 73, p. 1086-1103, jun. 2017. DOl:https://doi.org/10.1016/j.rser.2017.02.011

EVINS, R. A Review of Computational Optimisation Methods Applied to Sustainable Building Design. Renewable and Sustainable Energy Reviews, v. 22, p. 230-245, jun. 2013. DOI:https://doi.org/10.1016/j.rser.2013.02.004

FAJKUS, M. Superficial skins? Super Skins? Shading structures and thermal impact analysis. In: ADVANCED BUILDING SKINS - ENERGY FORUM, 2013, Itália. Proceedings [...]. Itália: 2013, p. 23-27.

FELIPPE, A. R. et al. Modelagem Paramétrica para simulação do desempenho da lluminação Natural e TermoEnergética da Edificação. In: CONGRESSO DA SOCIEDADE IBERO-AMERICANA DE GRÁFICA DIGITAL, 19., 2015, São Paulo. Proceedings [...].São Paulo: SIGRADI, 2015, p. 398-404.

FONSECA, Ligiana Pricila Guimarães et al . Otimização multiobjetivo das dimensões dos ambientes de uma residência unifamiliar baseada em simulação energética e estrutural. Ambient. constr., Porto Alegre , v. 17, n. 1, p. 267-288, mar. 2017. DOI:http://dx.doi.org/10.1590/s1678-86212017000100135.

GONZÁLEZ, J.; FIORITO, F. Daylight Design of Office Buildings: Optimization of External. Buildings, Sydney, v. 5, n. 2, p. 560-580, 2015. DOI:https://doi.org/10.3390/buildings5020560

GOSSARD, D.; LARTIGUE, B.; THELLIER, F. Multi-Objective Optimization of a Building Envelope for Thermal Performance Using Genetic Algorithms and Artificial Neural Network. Energy and Buildings, Oxford, v. 67, p. 253260, dec. 2013. DOl:https://doi.org/10.1016/j.enbuild.2013.08.026 
GUIMARÃES, I. Análises de incertezas e sensibilidade de arquivos climáticos e seus impactos em simulações computacionais termo energéticas. 2016. 109 f. Dissertação (Mestrado em Arquitetura e Urbanismo) Departamento de Arquitetura e Urbanismo, Universidade Federal de Viçosa, Viçosa. 2016.

JAKUBIEC, J. A.; REINHART, C. F. DIVA 2.0: Integrating Daylight and Thermal Simulations Using Rhinoceros 3D, Daysim and EnergyPlus. In: INTERNATIONAL CONFERENCE OF THE INTERNATIONAL BUILDING PERFORMANCE SIMULATION ASSOCIATION. 12., Sydeny. Proceedings [... ]. Toronto: IBPSA,2011, p. 2202-2209.

KHORASGANI, M.L.; BURRY, J.; SALEHI, M. Thermal performance of patterned facades: Studies on effects of patterns on the thermal performance of facades. In: EDUCATION AND RESEARCH IN COMPUTER AIDED ARCHITECTURAL DESIGN IN EUROPE, 32., 2014,Inglaterra. Proceedings [... ]. Inglaterra: eCAADe, 2014, p. 267-276.

KONIS, K.; GAMAS, A.; KENSEK, K. Passive performance and building form: An optimization. Solar Energy, Los Angeles, v. 125, p. 161-179, 2015. DOl:https://doi.org/10.1016/j.solener.2015.12.020

KRÜGER, E.; LAROCA, C. Thermal performance evaluation of a low-cost housing prototype made with plywood panels in Southern Brazil. Applied Energy, Curitiba, v. 87, p. 661-672, 2009.

DOl:https://doi.org/10.1016/j.apenergy.2009.06.038

MACHAIRAS, V.; TSANGRASSOULIS, A.; AXARLI, K. Algorithms for optimization of building design: A review. Renewable and Sustainable Energy Reviews, v. 31, p. 101-112, mar. 2014. DOl:https://doi.org/10.1016/j.rser.2013.11.036

MAGNIER, L.; HAGHIGHAT, F. Multi-objective Optimization of Building Design Using TRNSYS Simulations, Gentic Algorithm, and Artificial Neural Network. Building and Environment, v. 45, p. 739-746, 2010.

DOl:https://doi.org/10.1016/j.buildenv.2009.08.016

MAHMOUD, A. H. A.; ELGHAZI, Y. Parametric- based Designs for Kinetic Façades to Optimize Daylight Performance: Comparing Rotation and Translation Kinetic Motion for Hexagonal Façade Patterns. Solar Energy, v. 126, p. 111-127, mar. 2016. DOl:https://doi.org/10.1016/j.solener.2015.12.039

NARANGEREL, A.; LEE, J.; STOUFFS, R. Daylighting Based Parametric Design Exploration of 3D Facade Patterns. In: EDUCATION AND RESEARCH IN COMPUTER AIDED ARCHITECTURAL DESIGN IN EUROPE, 34., 2016, Finlândia. Proceedings [... ]. Finlândia: eCAADe, 2016, p. 379-388.

NGUYEN, A. T.; REITER, S.; RIGO, P. A Review on Simulation-Based Optimization Methods Applied to Building Performance Analysis. Applied Energy, v. 113, p. 1043-1058, jan. 2014.

DOI:https://doi.org/10.1016/j.apenergy.2013.08.061

NWOKOLO, S. C.; OGBULEZIE, J. C. A qualitative review of empirical models for estimating diffuse solar radiation from experimental data in Africa. Renewable and Sustainable Energy Reviews, v. 92, p. 353-393, set. 2018. DOl:https://doi.org/10.1016/j.rser.2018.04.118

OGBULEZIE, Julie C.; USHIE, Ogri James; NWOKOLO, Samuel Chukwujindu. A review of regression models employed for predicting diffuse solar radiation in North-Western Africa. Trends in Renewable Energy, [S.I.], v. 3, n. 2, p. 160206, nov. 2017. ISSN 2376-2144. DOI:http://dx.doi.org/10.17737/tre.2017.3.2.0042.

PESENTI, M.; MASERA, G.; FIORITO, F. Shaping an Origami shading device through visual and thermal. Energy Procedia, v. 78, p. 346-351, nov. 2015. DOl:https://doi.org/10.1016/j.egypro.2015.11.663

ROUDSARI, M. S.; PAK, M. LADYBUG: A Parametric Environmental Plugin for Grasshopper to Help Designers Create an Environmentally-Conscious Design. In: INTERNATIONAL CONFERENCE OF THE INTERNATIONAL BUILDING PERFORMANCE SIMULATION ASSOCIATION. 13., 2013, Chambery. Proceedings [... ]. Toronto: IBPSA, 2013, p. 31283135.

SADINENI, S. B.; MADALA, S.; BOEHM, R. F. Passive building energy savings: A review of building envelope components. Renewable and Sustainable Energy Reviews, v. 15, n. 8, p. 3618-3630, out. 2011.

DOI:https://doi.org/10.1016/j.rser.2011.07.014 
SANTANA, L. O.; GUIMARÃES, I. B. B.; CARLO, J. C. Parametrização Aplicada ao Desempenho Energético de Edificações. V!RUS, 11, 2015. Disponivel em: http://www.nomads.usp.br/virus/virus11/?sec=4\&item=4\&lang=pt. Acesso em: 03 Junho 2018.

STEVANOVIć, S. Optimization of passive solar design strategies: A review. Renewable and Sustainable Energy Reviews, v. 25, p. 177-196, 2013. DOI:https://doi.org/10.1016/j.rser.2013.04.028

\section{${ }^{1}$ Caio de Carvalho Lucarelli}

Arquiteto e Urbanista. Bacharel em Arquitetura e Urbanismo. Mestrando no Programa de Pós Graduação de Arquitetura e Urbanismo da Universidade Federal de Viçosa. Endereço postal: Av. P. H. Rolfs, s/nº, Centro, Viçosa, Minas Gerais, Brasil, 36570-900

\section{Joyce Correna Carlo}

Arquiteta e Urbanista. Doutora em Engenharia Civil. Professora do Departamento de Arquitetura e Urbanismo da Universidade Federal de Viçosa. Endereço postal: Av. P. H. Rolfs, s/nº, Centro, Viçosa, Minas Gerais, Brasil, 36570-900

\section{Andressa Carmo Pena Martinez}

Arquiteta e Urbanista. Doutora em Urbanismo. Professora adjunta, no setor de Projeto de Arquitetura e Urbanismo, do Departamento de Arquitetura e Urbanismo da Universidade Federal de Viçosa (DAU-UFV) e professora na pósgraduação em Arquitetura e Urbanismo na mesma instituição (PGAU/UFV. Endereço postal: Av. P. H. Rolfs, s/nº, Centro, Viçosa, Minas Gerais, Brasil, 36570-900 